\title{
Benefits of Farm Animals Genetic Adaptation: A Review
}

\author{
Solomon Tsegaye* and Hussen Ebrahim \\ Department of Animal Production and Technology, College of Agriculture, Woldia University, Mersa, Ethiopia
}

*Corresponding author: Solomon Tsegaye, Department of Animal Production and Technology, College of Agriculture, Woldia University, Mersa, Ethiopia, Tel: +251-913-733048; E-mail: solomontsegaye25@gmail.com

Received date: March 19, 2018; Accepted date: June 28, 2018; Published date: July 10, 2018

Copyright: @ 2018 Solomon T, et al. This is an open-access article distributed under the terms of the Creative Commons Attribution License, which permits unrestricted use, distribution, and reproduction in any medium, provided the original author and source are credited.

Citation: Solomon T, Hussen E (2018) Benefits of Farm Animals Genetic Adaptation: A Review. Eur Exp Biol Vol. 8 No. 4:22.

\section{Abstract}

This review aimed to deliver knowledge about the benefit of genetic adaptation of farm animals. Gene helps the farm animals to adapt conditions and able to survive different conditions. Furthermore, farm animal's genetic adaptation plays a great role to cope up climate change, environmental stresses including extreme hot and cold, disease and parasite. Accordingly, considering different factors, climatic condition, topography, breed type, relationship with human, disease and parasite resistance, welfare issue, physiological and behavioral status, nutritional habit in harsh environment and management influences, local and cross breeds are more important than exotic breeds to establish an international sustainable farm animal breeding program at farm and laboratory level. Likewise, in-situ and ex-situ adaptive local gene conservation bank should be done properly, especially, in developing countries. Therefore, the importance of this review is high and must be documented.

Keywords: Adaptation; Farm animal; Genetic adaptation

\section{Introduction}

Genetic adaptation is a characteristic with a heritable basis that will improve the reproductive and survival traits caused by domestication and natural evolution [1]. Genetic adaptation is of unknot major aim of evolutionary biology [2]. Consequently, genetic selection has got an attention to establish breeds which are more adapted, fast growing, productive and better disease and insect infestation resistant animals for supplying food and other livestock products to human beings in every parts of the world [3]. However, evidence for genetic adaptation in farm animals remains poorly understood [4].

Additionally, the influence of climate challenge on farm animal genetic resource adaptation and conservation related to human food supply and the alleviation mechanisms [5]. The significance of different livestock production systems to be part of the food source to mitigate the insecurity problem by conserving diversified animal genetic. However, unlimited mating, habitat distruction, unsustainable selective pressures for adaptation to global climate changes, over exploitation and loss of community structure are major threats to conservation of farm animal genetic resources [6-8].

Moreover, there have been losing of farm animal genetic material in some place as a result of globalization [9] and many local breeds have a small population mass due to the cause of inability to adapt resulting extinction [10]. Therefore, the paper aimed to review about the benefit of genetic adaptation of farm animals.

\section{Benefits of Farm Animal Genetic Adaptation}

Animal genetic resources (AnGR) are required to put a solution for world food insecurity challenge especially in in developing countries at livelihood. Livestock provides products with great amout of energy, protein, vitamins and minerals mostly for infants and mothers. Livestock sector supports more than a billion people particularly the rural people which are predominantly poor [11]. The need and competion to use animals and their products have been significantly increasing throughout the century and this will be expected to rise in the coming years. About $70 \%$ of the world local farm animals' are recorded cattle, sheep, chicken, goat and horse and the need of farm animal gene expression for adaptation record and in-situ and ex-situ gene conservation environments [12] (Table 1).

\section{Farm animal genetic adaptation to supply human with food}

In 35th world animal genomics conference, reported the world human population will increase rapidly from 7.3 billion to 9.6 billion by 2050 and food production must be doubled despite the challenges of climate change, limited land and water resources [13]. Therefore, a better understanding of the underlying genomic control of adaptation in native and exotic livestock will be required to meet the growing human needs. Keeping the diversity of the genetic resources in the way to transfer to the next generation is mandatory. The availability and cheap animal genomic technologies provided benefit for the livestock producers and consumers in the developed world. 
These tools shall also deliver new opportunities for the developing world.

Table 1: Numbers of local breeds recorded per species and region for the five main farm animal species for food and agriculture.

\begin{tabular}{|l|l|l|l|l|l|l|l|l|}
\hline Species & Africa & Asia & $\begin{array}{l}\text { Europe and the } \\
\text { Caucasus }\end{array}$ & $\begin{array}{l}\text { Latin America } \\
\text { and Caribbean }\end{array}$ & $\begin{array}{l}\text { Near and } \\
\text { North } \\
\text { Middle east }\end{array}$ & $\begin{array}{l}\text { North } \\
\text { America }\end{array}$ & $\begin{array}{l}\text { South West } \\
\text { Pacific }\end{array}$ \\
\hline Cattle & 176 & 241 & 369 & 141 & 43 & 17 & 32 & 1,019 \\
\hline Chicken & 129 & 305 & 912 & 88 & 35 & 15 & 30 & 1,514 \\
\hline Sheep & 117 & 262 & 613 & 51 & 53 & 21 & 38 & 1,155 \\
\hline Horse & 40 & 138 & 371 & 84 & 14 & 22 & 25 & 694 \\
\hline Goat & 96 & 183 & 218 & 28 & 34 & 6 & 17 & 11 \\
\hline Total & 558 & 1,129 & 2,483 & 392 & 81 & 136 \\
\hline
\end{tabular}

Genetic adaptation of farm animal functional traits for economic profitability and welfare issues

Functional traits play a critical role in biological and economic efficiency by reducing costs of production. Consumers demand of farm animals product is growing; as a result it needs supply of safe, quality and low cost product by giving attention to farm animal welfare. In this case, to establish effective and efficient breeding program there should be a consideration of functional traits [14].

\section{Farm animal genetic adaptation in pastoral environment}

Adaptation is influenced by genetic make-up and it determines an animal's tolerance to adverse conditions such as high temperature, drought, pests and diseases. Adaptation as a result of heritable feature of genes of farm animals favor survival of a population. Many breeds of the harsh environment have developed many adaptive traits that increase their survivability [15]. The existence and fruitful reproduction of farm animals which are genetically adapted to a specific environment is majorly determined by natural selection.

Smallholder pastoralists and their animals lived in harsh environments which may be extremely cold or hot. Moreover, these environments can be characterized by scarcity of feed, water resources and high disease pressure with large seasonal and annual variation of rainfall. In this condition, the farm animal genes have a potential role to allow animals to live under stressful conditions. The first stragy of breeders is to keep the environmt confortable by considering the need of animal. The other altenative is to raise locally adapted animals. In the second case, managing diverse and mixed farm animal enable them to live, produce and reproduce in their environment under a given production system [16].

\section{Climate change and farm animal genetic adaptation}

Conserving satisfactory multiplicity of AnGR is necessary to safeguard adaptation prospective in times of uncertainty to overcome the probable climate change problem which will be a major force testing elasticity of global food production systems
$[17,18]$. Adaptation to climate change is improbable to be accomplished with a single strategy [6]. Therefore research commitment and application of genomics will support the measures taken for farm animals to be able to coupup the climate change.

So far, many livestock breeds have been genetically characterized [19] but the value of this study of adaptation is debatable. The best mechanism to tolerate climate change is rearing local breeds adapted to harsh environments. Most developed country breeds have been studied for the past many decades in case climate is managed. Explainning the production system in aprticular area to get the required information should be done by observing geographical features which further needs to investigate the implication of adaptation [20], socio-economic evidence [21] and local breed management information with in its habitat. Therefore, crossbreeding can be a valuable strategy for achieving increased productivity and adaptability.

Genetic adaptation basically increases productivity, efficiency and maintenance of genetic diversity which allow more opportunities to match breeds to a changing climate [22].

Several adaptive genes are involved in cross-talks between processes and in part through the regulation of transcription. Selection allows adaptation of functionally diverse loci with high gene flow and small allel frequency [2].

\section{Conclusion and Recommendations}

The fastest growing world human population demand for food is becoming beyond the carrying capacity of the land. As a result farm animals contribution to fill the food gap is getting an attention and different improvement programs were established in different parts of the world. Accordingly, genetic adaptation determines the effectiveness of production, behavioral and survival capacity of animals. Especially, natural selection plays a vital role to get an adapted farm animal gene for higher output, safe welfare and sustainable utilization without any detrimental effect through time $[23,24]$.

However, evidence for genetic adaptation in farm animals remains poorly understood which caused quality depletion of genes. In addition, the global climate change, disease outbreak, 
parasite infestation, scaresity of animal forage and water also become a challenge of farm animal genetic adaptation in developing nations. Furthermore, understanding the genetic adaptation of farm animals, conservation and record keeping of local breeds have a great role to global food security. Therefore, conservation of locally adapted indigenous farm animals breed is an important objective of sustainable animal breeding program.

\section{References}

1. Farooq U, Samad HA, Chaudhr HR, Qayyum A (2010) Physiological Responses of cattle to Heat Stress. World Applied Sciences Journal 38-43.

2. Benjamin H, Nathalie P, Sebastien G, Jean B (2015) Genetic Adaptation to Climate Involves Small to Moderate Allele Frequency Shifts in Functionally Diverse Genes. Genome Biology and Evolution 7: 3269-3285.

3. Louis-Marie H (2014) Impacts of genetically modified animals on the ecosystem and human activities. Global Bioethics 25: 3-18.

4. Karlsson AC (2014) Effects of domestication related genes on behaviour, physiology and gene expression in chickens. Linkoping University Electronic Press 48.

5. Kantanen J, Lovendahl P, Strandberg E, Eythorsdottir E, Meng HL (2015) Utilization of farm animal genetic resources in a changing agro-ecological environment in the Nordic countries. Front Genet 6: 52.

6. Hoffmann I (2010) Climate change and the characterization, breeding and conservation of animal genetic resources. Anim Genet 41: 32-46.

7. Pilling D, Hoffman I (2011) Climate Change and Animal Genetic Resources for Food and Agriculture: State of Knowledge, Risks and Opportunities. Background Study Paper 53.

8. Allendorf FW, Leary RF, Spruell P, Wenburg JK (2001) The problems with hybrids: setting conservation guidelines. Trends Ecol Evol 16: 613-622.

9. IFAD (2009) Comprehensive Report on IFAD's Response to Climate Change through Support to Adaptation and Related Actions (Draft).

10. FAO (2013) In Vivo Conservation of Animal Genetic Resources. FAO Animal Production and Health Guidelines. No. 14. Rome: FAO.
11. FAO (2009) The State of Food and Agriculture - Livestock in the Balance. Rome.

12. Boettcher PJ, Hoffmann I, Baumung R, Drucker AG, McManus C, et al. (2015) Genetic resources and genomics for adaptation of livestock to climate change. Front Genet 5: 461.

13. Rothschild MF (2016) Applications of genomics to address adaptation of livestock to stressful environments to prevent food insecurity in the developing world, S0112. Journal of Animal Science.

14. Barillet $F$ (2007) Genetic improvement for dairy production in sheep and goats. Small Ruminant Research 70: 60-75.

15. Naskar S, Gowane GR, Chopra A, Paswan C, Leo LP (2012) Genetic adaptability of livestock to environmental stresses In: Sejian V., Ezeji T., Lakritz J. and Lal R. (eds) environmental stress and amelioration in livestock production. Springer Verlag publisher, New York 319-374.

16. Mirkena T, Duguma G, Haile A, Tibbo M, Okeyo AM, et al. (2010) Genetics of adaptation in domestic farm animals: A review. Livestock Science 132: 1-12.

17. Thornton PK, Steeg JV, Notenbaert A, Herrero M (2009) The impacts of climate change on livestock and livestock systems in developing countries: a review of what we know and what we need to know. Agricult Syst 101: 113-127.

18. Renaudeau D, Collin A, Yahav S, BasilioV, Gourdine JL, et al. (2012) Adaptation to hot climate and strategies to alleviate heat stress in livestock production. Animal 6: 707-728.

19. Groeneveld LF, Lenstra JA, Eding H, Toro MA, Scherf B, et al. (2010) Genetic diversity in farm animals- a review. Anim Genet 41: 6-31.

20. FAO (2012) Phenotypic Characterization of Animal Genetic Resources. FAO Animal Production and Health Guidelines No. 11. Rome.

21. Drucker AG (2010) Where's the beef? The economics of AnGR conservation and its influence on policy design and implementation. Anim. Genetic Resour 47: 85-90.

22. Fourcada J, Hoffman JI (2014) Climate change selects for heterozygosity in a declining fur seal population. Nature 511: 462-465.

23. Niyas P, Chaidanya K, Shaji S, Sejian V, Bhatta R (2015) Adaptation of Livestock to Environmental Challenges. J Vet Sci Med Diagn 4:3.

24. Randi E (2008) Detecting hybridization between wild species and their domesticated relatives. Mol Ecol 17: 285-293. 